\title{
Photosynthesis, respiration and dry matter production of Scots pine (Pinus silvestris L.) seedlings originating from Poland (Nowy Targ) and Turkey (Eskishaher)
}

FADHIL OMRAN AL-SHAHINE

Most of the investigation in provenance testing takes into account growth rates and morphological features but there are also some data available (see literature reviews: Kozłowski and Keller 1966, Białobok 1967, and Żelawski 1967) indicating physiological variation to be fundamentally involved. However, this physiological background of variation within plant species is very little known although its knowledge would have great importance for breeding and introduction work. Especially species occupying large distribution area are interesting for such research since growing naturally under differentiated conditions they may have developed into various ecotypes, races, or strains diversely adapted to the local sites.

Study on photosynthetic ability of Scots pine deriving from distant localities but cultivated at similar conditions may help better to comprehend the process of ecotypical differentiation within the species. In this paper seedlings of Scots pine originating from Poland and Turkey were compared after cultivating them for one, two or three years in greenhouse or nursery conditions of the Experimental Forest Station Rogów (central Poland). The functionning of assimilatory organs was main purpose of research as photosynthetic uptake of $\mathrm{CO}_{2}$ is the process essentially contributing in dry matter production.

\section{PLANT MATERIAL AND METHODS}

The seed originated from natural, presumably native stands of mountain regions in Poland (Nowy Targ) and in Turkey (Eskishaher). Experiments were carried out at the Experimental Forest Station Rogów which belongs to the Forestry Faculty of Warsaw Agricultural University (coordinates see table 1). Plant material used for experiments has been cultivated either in nursery conditions or in standard pots filled with the forest soil. In pot experiments watering to the constant weight enabled the maintenance of soil moisture content at the level of about $60 \%$ of capillary capacity. Pots stood usually out - of - doors, under a wire net and were 
Table 1

Coordinates of seed sources and plantation locality

\begin{tabular}{|l|l|l|c|c|c|}
\hline Country & \multicolumn{1}{|c|}{ Region } & $\begin{array}{c}\text { Forest } \\
\text { district }\end{array}$ & Latitude & Longitude & Altitude o.s. \\
\hline \multirow{2}{*}{ Poland } & $\begin{array}{l}\text { Tatra } \\
\text { Pighland }\end{array}$ & Nowy Targ & $49^{\circ} 27^{\prime}$ & $20^{\circ} 01^{\prime}$ & $620 \mathrm{~m}$ \\
\multirow{2}{*}{ Turkey } & $\begin{array}{l}\text { Central } \\
\text { Poland }\end{array}$ & Rogów & $51^{\circ} 40^{\prime}$ & $19^{\circ} 53^{\prime}$ & $185 \mathrm{~m}$ \\
\hline
\end{tabular}

wheeled under the glass for nights and rainy periods. Seedlings of the first, second or third vegetation season were used in particular experiments. Growth analysis based on dry matter determination, manometer technique, infrared $\mathrm{CO}_{2}$ analyzer were the main methods of this research work; chlorophyll determinations were carried out spectrophotometrically in $85 \%$ acetone extracts (MacKinney 1941, Briunsma 1963). More detailed discription of the methods applied will be given at discussing various in experiments.

\section{Growth analysis in seedlings grown in nursery}

During the year 1966 (May-December) pine seedlings were cultivated in nursery conditions for gathering preliminary data on growth characteristics and dry matter production. During the first vegetation season seedlings were harvested several times in 4 week intervals with the purpose of determination of growth characteristics and net assimilation rates. 20 seedlings were always sampled as the representatives for calculation of means. In fig. 1 main features of dry matter accumulation of these plants are presented. They indicate that during the first year of growth in nursery conditions of Forest Experimental Station Rogów the pine of Turkish origin attains somewhat higher dry weight in all organs (needles, roots, and stems) than this from Polish highland region. Height of both was, however, the same and amounted, on the average, $30 \mathrm{~mm}$ at the end of the vegetation season.

On the basis of dry matter determinations the net assimilation rate (NAR) was calculated using two different formula (see review of the method - Łotocki (1969).

1)

$$
\begin{aligned}
& \text { NAR }=\frac{\left(\mathrm{W}_{2}-\mathrm{W}_{1}\right)\left(\ln \mathrm{L}_{2}-\ln \mathrm{L}_{1}\right)}{\left(\mathrm{L}_{2}-\mathrm{L}_{1}\right)\left(\mathrm{t}_{2}-\mathrm{t}_{1}\right)} . \\
& \mathrm{NAR}=\frac{2\left(\mathrm{~W}_{2}-\mathrm{W}_{1}\right)}{\left(\mathrm{L}_{2}-\mathrm{L}_{1}\right)\left(\mathrm{t}_{2}-\mathrm{t}_{1}\right)},
\end{aligned}
$$

where $\mathrm{W}_{1}$ and $\mathrm{W}_{2}$ are the dry weights of the plant and $\mathrm{L}_{1}$ and $\mathrm{L}_{2}$ are the dry weights of needles at times $t_{1}$ and $t_{2}$ respectively. 
The data indicate that both investigated pines differ in this respect, pine of Polish provenance being more efficient throughout most of the vegetation season when dry matter of needles is used as a reference unit. Both values obtained by means of logarythmic or simple formula gave usually similar numbers especially in Eskishaher pine.

During the year 1968, after two vegetation seasons spent in nursery conditions the dry matter accumulation was investigated again. Five replicates, containing

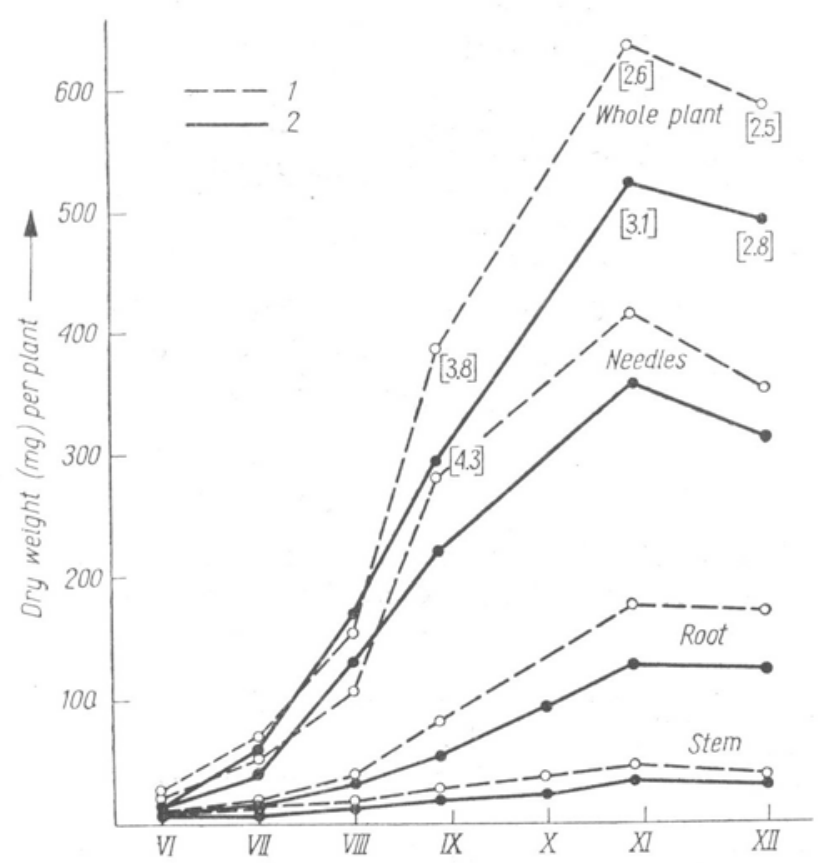

Fig. 1. Mean Course of dry weight during the first vegetation season (the numbers in brackets indicate the shoot/root ratio)

1 - Eskishaher; 2 - Nowy Targ

50 plants each were carefully digged out of the soil and after washing, separating the needles, stems and roots, and drying the samples at $105^{\circ} \mathrm{C}$ the dry matter was determined and net assimilation rates calculated for the period June 26 - July 22. In contrast to the first year plants, in seedlings of the third vegetation season the retarded growth of Eskishaher pine was noted (fig. 2); the final height at the end of the vegetation season was $28.5 \mathrm{~cm}$ in pine of Polish provenance and only $20.6 \mathrm{~cm}$ in that of Turkish one. The average daily production of dry matter per $\mathrm{g}$ of dry weight of needles (NAR) was then $36 \mathrm{mg}$ in pine of Polish origin and only $25 \mathrm{mg}$ in that from Turkey; in this case the difference in photosynthetic efficiency was even more pronounced than during the first year of growth. 
In both nursery experiments (1966 and 1968) the ratio shoot root was determined. As seen from fig. 1 and 2, pine of Polish provenance showed higher ratio S/R than of Turkish provenance. Also in experiments carried out with pot seedlings

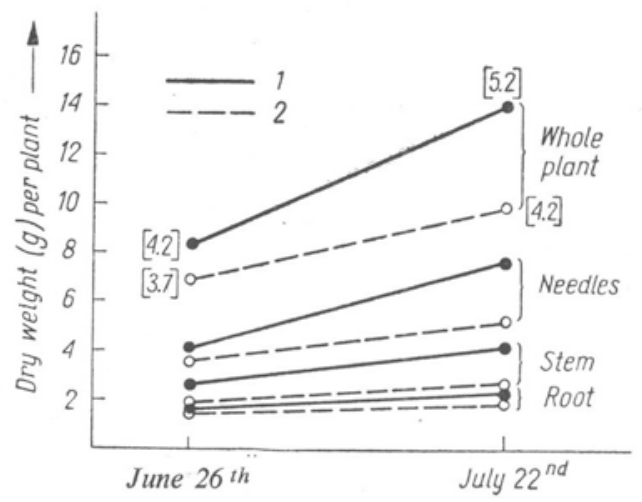

Fig. 2. Mean chatacteristics of dry weight during the third vegetation season (the numbers in brackets indicate the shoot/ root ratio

1 - Nowy Targ; 2 - Eskishaher

Table 2

Net assimilation rates in seedlings of the first and third vegetation season (mg of dry weight. $\mathrm{g}^{-1}$ of needles dry weight day ${ }^{-1}$ )

\begin{tabular}{|c|c|c|c|c|c|}
\hline 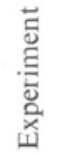 & 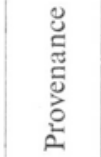 & $\begin{array}{c}\text { Period } \\
\text { of investigation }\end{array}$ & $\begin{array}{c}\text { No. } \\
\text { of } \\
\text { days }\end{array}$ & $\begin{array}{c}\mathrm{NAR}= \\
=\frac{\left(\mathrm{W}_{2}-\mathrm{W}_{1}\right)\left(\ln \mathrm{L}_{2}-\ln \mathrm{L}_{1}\right)}{\left(\mathrm{L}_{2}-\mathrm{L}_{1}\right)\left(\mathrm{t}_{2}-\mathrm{t}_{1}\right)}\end{array}$ & $N A R=\frac{2\left(W_{2}-W_{1}\right)}{\left(L_{2}+L_{1}\right)\left(t_{2}-t_{1}\right)}$ \\
\hline 苛 & 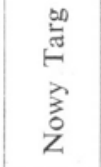 & $\begin{array}{l}\text { June/July } \\
\text { July/August } \\
\text { August/Septemb. } \\
\text { Septemb./Nov. }\end{array}$ & $\begin{array}{l}29 \\
31 \\
28 \\
63\end{array}$ & $\begin{array}{l}72 \\
48 \\
26 \\
13\end{array}$ & $\begin{array}{l}64 \\
44 \\
26 \\
14\end{array}$ \\
\hline 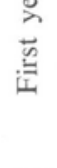 & 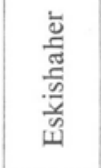 & $\begin{array}{l}\text { June/July } \\
\text { July/August } \\
\text { August/Septemb. } \\
\text { Sept./Nov. }\end{array}$ & $\begin{array}{l}29 \\
30 \\
28 \\
63\end{array}$ & $\begin{array}{l}56 \\
39 \\
46 \\
11\end{array}$ & $\begin{array}{l}55 \\
37 \\
43 \\
11\end{array}$ \\
\hline ङ્ّ & $\begin{array}{l}\text { Nowy } \\
\text { Targ }\end{array}$ & June/July & 27 & 37 & 36 \\
\hline$\stackrel{\mathscr{E}}{\stackrel{E}{E}}$ & $\begin{array}{c}\text { Eskish- } \\
\text { aher }\end{array}$ & June/July & 27 & 25 & 25 \\
\hline
\end{tabular}

used for gasometric determinations of gas exchange (see below) the ratio $\mathrm{S} / \mathrm{R}$ was higher in Nowy Targ pine (table 12).

Final growth of plants at the end of the third vegetation season is seen in table 3 . 


\section{Table 3}

Growth characteristics of the investigated seedlings at the end of the third vegetation season

(an average of 80 plants for every pine provenance)

\begin{tabular}{|l|c|c|c|c|}
\hline \multicolumn{1}{|c|}{ Provenance } & $\begin{array}{c}\text { height of plant } \\
(\mathrm{cm})\end{array}$ & $\begin{array}{c}\text { shoot length } \\
(\mathrm{cm}) \\
\text { last incriment }\end{array}$ & $\begin{array}{c}\text { number of } \\
\text { needles per plant }\end{array}$ & $\begin{array}{c}\text { dry weight of a } \\
\text { single needle (mg) }\end{array}$ \\
\hline Nowy Targ & 28.5 & 20.7 & 314 & 10.2 \\
Eskishaher & 20.6 & 13.6 & 360 & 10.0 \\
\hline
\end{tabular}

2. Characteristic of assimilatory organs

From the experiment carried out during the year 1966 in nursery conditions some data on needles characteristics were obtained (table 4). Size of needles of both investigated pines seemed to be almost the same, but significant difference existed in the number of needles per shoot.

Table 4

Mean characteristics of juvenile needles from the experiment in nursery, during the first vegetation seaon

\begin{tabular}{|l|c|c|c|}
\hline \multicolumn{1}{|c|}{ Period of investigation } & Characteristic & \multicolumn{2}{|c|}{ Provenance } \\
\cline { 2 - 3 } $\begin{array}{l}\text { October 14- } \\
\text { December 22, 1966 }\end{array}$ & $\left\{\begin{array}{l}\text { Number of needles per one seedling } \\
\text { Dry weight of a single needle (mg) }\end{array}\right.$ & $\begin{array}{c}129 \\
2.4\end{array}$ & \begin{tabular}{c} 
Eskishaher \\
\hline
\end{tabular} \\
\hline
\end{tabular}

\section{Table 5}

Mean characteristics of juvenile needles from the experiment in greenhouse, during the first vegetation season

\begin{tabular}{|c|c|c|c|}
\hline \multirow{2}{*}{ Period of investigation } & \multirow{2}{*}{ Characteristic } & \multicolumn{2}{|c|}{ Provenance } \\
\hline & & Nowy Targ & Eskishaher \\
\hline \multirow{2}{*}{ September - } & Dry weight of a single needle $(\mathrm{mg})$ & 2.7 & 4.0 \\
\hline & length $(\mathrm{mm})$ & 37 & 37 \\
\hline \multirow[t]{3}{*}{ October 1967} & Chlorophyll content ( $\mathrm{mg} / 1000$ needles) & 13.5 & 18.7 \\
\hline & $\begin{array}{l}\text { Chlorophyll content }(\mathrm{mg} / \mathrm{g} \text { of } \\
\text { needle dr. wt.) }\end{array}$ & 5.0 & 4.7 \\
\hline & Chlorophyll $\mathrm{a} / \mathrm{b}$ ratio & 2.5 & 2.3 \\
\hline
\end{tabular}

Formation of the assimilatory organs may be different in various vegetation conditions as it can be seen from data in tables 5-8. During the year 1967 pot experiments in greenhouse were carried out and samples of needles for photosynthesis measurements (described below) were taken from one and two years old seedlings. 
Table 6

Mean characteristics of paired needles in fascicles from the experiment in greenhouse, during the second vegetation season

\begin{tabular}{|c|c|c|c|}
\hline \multirow{2}{*}{ Period of investigation } & \multirow{2}{*}{ Character istic } & \multicolumn{2}{|c|}{ Provenance } \\
\hline & & Nowy Targ & Eskishaheı \\
\hline \multirow{6}{*}{$\begin{array}{l}\text { September, } \\
\text { October, and November } \\
1967\end{array}$} & Dry weight of a single needle (mg) & 9.5 & 9.0 \\
\hline & Length $(\mathrm{mm})$ & 84 & 73 \\
\hline & Chlor ophyll content $(\mathrm{mg} / 1000$ & & \\
\hline & $\begin{array}{l}\text { needles) } \\
\text { Chlorophyll content }(\mathrm{mg} / \mathrm{g} \text { of }\end{array}$ & 45 & 38 \\
\hline & needles dry wt) & 4.7 & 4.2 \\
\hline & Chlorophyll $\mathrm{a} / \mathrm{b}$ ratio & 2.3 & 2.4 \\
\hline
\end{tabular}

These numbers were not so representative as data of the nursery experiment since only $4-8$ needles were chosen from each seedling and limited number of seedlings (25) was taken for measurements, but they indicate that pine of Turkish provenance may develop larger needles than that of Polish origin (when size is expressed as dry weight of a single needle); the length was, however, almost the same in both investigated pines. The paired needles appearing in fascicles on seedlings of the second vegetation season (table 6) were, during the year 1967, remarkably shorter

\section{Table 7}

Mean characteristics of paired needles in fascicles from the experiment in nursery, during the third vegetation season

\begin{tabular}{|l|c|c|c|}
\hline \multicolumn{1}{|c|}{ Period of investigation } & \multicolumn{2}{|c|}{ Provenance } \\
\hline $\begin{array}{l}\text { June 26- } \\
\text { July 22,1968 }\end{array}$ & $\left\{\begin{array}{l}\text { Dry weight of a single needle }(\mathrm{mg}) \\
\text { Length }(\mathrm{mm})\end{array}\right.$ & $\begin{array}{l}10.6 \\
57\end{array}$ & $\begin{array}{c}\text { Now } \\
\text { Lentic }\end{array}$ \\
\hline
\end{tabular}

Table 8

Mean dry matter of needles from pot seedlings cultivated in greenhouse conditions during the second vegetation season

\begin{tabular}{|l|c|c|c|}
\hline \multirow{2}{*}{ Period of investigation } & Characteristic & \multicolumn{2}{|c|}{ Provenance } \\
\cline { 2 - 4 } & Nowy Targ & Eskishaher \\
\hline June/July 1968 & Dry weight of a single needle (mg) & 5.1 & 3.4 \\
August 1968 & Dry weight of a single needle (mg) & 7.0 & 4.7 \\
\hline
\end{tabular}

in pine of Turkish provenance, but they were, on the average, of nearly the same weight in both investigated pines. On the other hand the data of another experiment, carried out on nursery seedlings during the third vegetation season (table 7) have shown, that length of needles is very much the same in both investigated pines whereas their dry weight is slightly lower in seedlings of Turkish provenance. 
Pot seedlings used for photosynthesis measurements in IRGA (table 8) showed also and even more distinctly the difference in the dry matter of needles of both investigated pine: in this case needles of Nowy Targ were significanty heavier than those of Eskishaher pine.

As to the chlorophyll content the data are rather scanty (table 5 and 6). It seems that also in this respect the investigated pines are somewhat different which would confirm the general impression of some colour differences to be seen in nursery experiment.

\section{Manometric determinations of photosynthesis and respiration}

Seedlings cultivated in greenhouse conditions were used for determination of gaseous exchange during the vegetation season 1967. Seedlings grown in nursery were also the object of research during their third vegetation season, i.e. in the year 1968 .

Manometer technique (direct Warburg method) was applied for photosynthesis and respiration determinations. In the experiments 1967 the standard vessels of about $15 \mathrm{~cm}^{3}$ of volume were used whereas in the next year experiments the special form of vessels was prepared as described in the paper of Żelawski and Kinelska (1969). Horizontal arrangement of vessels enabled the most favourable exposure of needles to light and the most proper conditions of $\mathrm{CO}_{2}$ - exchange between the gaseous and liquid phases. As the source of $\mathrm{CO}_{2}$ the carbonate buffer, consisting of $\mathrm{K}_{2} \mathrm{CO}_{3}$ and $\mathrm{KHCO}_{3}(1: 1)$ in concentration $2.0 \mathrm{M}$ was used (Warburg and Krippah1 1960). Measurement conditions were as follows: $\mathrm{CO}_{2}$ concentration $0.55 \mathrm{v} \%$, temperature $25^{\circ} \mathrm{C}$ (water bath), illumination about 20.000 lux from four incandescent lamps of reflector type, $500 \mathrm{~W}$ each, through $8 \mathrm{~cm}$ thick water screen. Dark respiration measurements followed the determinations of photosynthesis and the whole experiment including photosynthesis and dark respiration measurements usually lasted no longer than $1.5-2.5$ hours from the detachment of needles.

Table 9

Mean values of photosynthesis and respiration rates in juvenile needles; pot experiment in greenhouse, first vegetation season

(Warburg determination)

\begin{tabular}{|c|c|c|c|}
\hline \multirow{2}{*}{$\begin{array}{c}\text { Period } \\
\text { of investigation }\end{array}$} & \multirow{2}{*}{ Rate of the process ( $\mathrm{ml} \mathrm{O}_{2} /$ hour) } & \multicolumn{2}{|c|}{ Provenance } \\
\hline & & Nowy Taig & Eskishaher \\
\hline 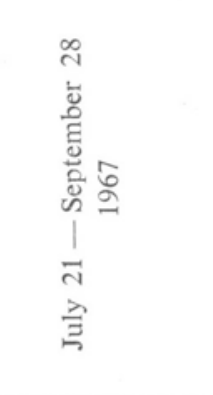 & $\begin{array}{l}\text { Photosynthesis } \\
\text { per } 1 \mathrm{~g} \text { of needles dry weight } \\
\text { per } 1000 \text { needles } \\
\text { per } 1 \mathrm{mg} \text { of chlorophyll } \\
\text { per } 100 \mathrm{dm} \text { of needles length } \\
\text { Respiration } \\
\text { per } 1 \mathrm{~g} \text { of needles dry weight } \\
\text { per } 1000 \text { needles } \\
\text { per } 100 \mathrm{dm} \text { of needles length } \\
(\mathrm{A}+\mathrm{R}) / \mathrm{R} \text { ratio: }\end{array}$ & $\begin{aligned} & 0.97 \\
& 2.4 \\
& 0.7 \\
\cong & 6.4\end{aligned}$ & $\begin{aligned} & 1.25 \\
& 3.8 \\
& 1.2 \\
\cong & 5.4\end{aligned}$ \\
\hline
\end{tabular}


Measurements were carried out in various times of the year, but for calculation of mean values of photosynthesis and respiration presented below the summer period was chosen when the rates per $g$ of needles dry weight were almost constant. These data tabulated in tables 9-11 clearly indicate that two investigated pines significantly differ in photosynthesis rate. In each of these three experiments, inrespective of the reference unit applied photosynthesis rate was always higher in pine of Turkish provenance in comparison with the Polish one. This gives evidence about higher photosynthetic ability of pine from southern parts of distribution area of the species when investigated in nearly optimum laboratory conditions. Although the difference appeared in all experiments carried out with greenhouse or nursery plants the difference was especially clearly pronounced in seedlings during their third year of growth.

\section{Table 10}

Mean values of photosynthesis and respiration rates in paired needles on fascicles pot experiment in greenhouse, second vegetation season

(Warburg determination)

\begin{tabular}{|c|c|c|c|c|}
\hline \multirow{2}{*}{$\begin{array}{c}\text { Period } \\
\text { of investigation }\end{array}$} & \multirow{2}{*}{\multicolumn{2}{|c|}{ Rate of the process $\left(\mathrm{ml} \mathrm{O}_{2} /\right.$ hour $)$}} & \multicolumn{2}{|c|}{ Provenance } \\
\hline & & & Nowy Targ & Eskishaher \\
\hline 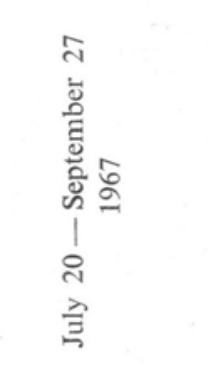 & $\begin{array}{l}\text { Photosynthesis } \\
\text { per } 1 \mathrm{~g} \text { of needles dry weight } \\
\text { per } 1000 \text { needles } \\
\text { per } 1 \mathrm{mg} \text { of chlorophyll } \\
\text { per } 100 \mathrm{dm} \text { of needles length } \\
\text { Respiration } \\
\text { per } 1 \mathrm{~g} \text { of needles dry weight } \\
\text { per } 1000 \text { needles } \\
\text { per } 100 \mathrm{dm} \text { of needles length } \\
(\mathrm{A}+\mathrm{R}) / \mathrm{R} \text { ratio: }\end{array}$ & - & $\begin{array}{l}0.72 \\
6.1 \\
0.79 \\
\sim 7\end{array}$ & $\begin{aligned} & 0.75 \\
& 5.7 \\
& 0.80 \\
& \sim 8\end{aligned}$ \\
\hline
\end{tabular}

Table 11

Mean values of photosynthesis and respiration rates in paired needles on fascicles; nursery experiments, third vegetation season

(Warburg determination)

\begin{tabular}{|c|c|c|c|}
\hline \multirow{2}{*}{$\begin{array}{c}\text { Period } \\
\text { of investigation }\end{array}$} & \multirow{2}{*}{ Rate of the process ( $\mathrm{ml} \mathrm{O}_{2} /$ hour) } & \multicolumn{2}{|c|}{ Provenance } \\
\hline & & Nowy Targ & Eskishaher \\
\hline 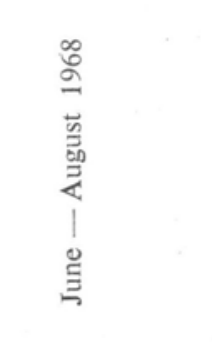 & $\begin{array}{l}\text { Photosynthesis } \\
\text { per } 1 \mathrm{~g} \text { of needles dry weight } \\
\text { per } 1000 \text { needles } \\
\text { per } 100 \mathrm{dm} \text { of needles length } \\
\text { Respiration } \\
\text { per } 1 \mathrm{~g} \text { of needles dry weight } \\
\text { per } 1000 \text { needles } \\
\text { per } 100 \mathrm{dm} \text { of needles length } \\
(\mathrm{A}+\mathrm{R}) / \mathrm{R} \text { ratio: }\end{array}$ & $\begin{aligned} & 0.9 \\
& 8.7 \\
& 1.6 \\
& \sim 8\end{aligned}$ & $\begin{array}{r}0.9 \\
8.0 \\
1.4 \\
\sim 11\end{array}$ \\
\hline
\end{tabular}


Respiration rate was not so clearly differentiated and it can be assumed that no significant difference existed in this respect except the juvenile stage of development when the respiration of Eskishaher pine was also higher than that of Nowy Targ pine. As a result ratio of true photosynthesis to dark respiration, $[(A+R) / R]$ was higher in Eskishaher pine than in Nowy Targ pine with exception of first year seedlings when opposite was true.

\section{Gasometric determinations of photosynthesis and respiration rates}

Another part of plants material grown in pot experiments, under semi-controlled greenhouse conditions was used for photosynthesis and respiration determinations in a closed circuit system of an infra-red $\mathrm{CO}_{2}$ analyzer. There were two experiments carried out during the second vegetation season on plants transferred from outside into laboratory conditions at the end of June 1968 and at the beginning of August 1968.

The method of gas exchange determinations was described in detail in the previous works from this laboratory (Żelawski and Górai 1966, Żelawski and Kucharska 1967, Żelawski and Kinelska 1967). The experimental conditions were as follows: $\mathrm{CO}_{2}-$ concentration $350-300 \mathrm{ppm}$, illumination from combined incandescent and fluorescent lamps below the saturation light intensity, temperature of the air $25^{\circ} \mathrm{C}$ controlled by an ultrathermostat in the photosynthetic doublewalled plexiglass chamber, air humidity inside of the closed circuit system was low because of necessity of drying air incoming into the $\mathrm{CO}_{2}$ - analyzer.

Table 12

Mean characteristics of dry weight of seedlings from pot experiment, during their second vegetation season

\begin{tabular}{|l|l|c|c|}
\hline $\begin{array}{c}\text { Period } \\
\text { of investigation }\end{array}$ & \multicolumn{1}{|c|}{ Characteristic } & \multicolumn{2}{|c|}{ Provenance } \\
\cline { 2 - 4 } June/July 1968 & \multicolumn{1}{|c|}{ Nowial parts (g) } & 2.50 & 1.21 \\
& Root system (g) & 0.58 & 0.32 \\
& Total dry weight of a plant (g) & 3.08 & 1.53 \\
August 1968 & \multicolumn{1}{|c|}{ Shoot/root ratio } & 4.3 & 3.8 \\
& Aerial parts (g) & 2.62 & 1.59 \\
& Root system (g) & 0.72 & 0.53 \\
& Total dry weight of a plant (g) & 3.34 & 2.12 \\
& \multicolumn{1}{|c|}{ Shoot/root ratio } & 3.6 & 3.0 \\
\hline
\end{tabular}

In many previous experiments it was already found that cutting has no noticeable effect on measurements data when the determination are made within a few minutes time interval after detachament. Therefore, all experiments were carried out on excised shoots taken from plants which had initially been adapted to the given experimental conditions. Measurement of respiration in darkness followed 
the gas exchange determinations in light. After that the root system was carefully extracted from the soil and its respiration rate was measured. Plants were then divided into particular parts and dry weight of needles, stems, and roots was determined after drying to the constant weight at $105^{\circ} \mathrm{C}$.

Altogether 10 plants of each provenance were measured in the described manner àt every sampling date. Mean data on seedlings characteristics are given in table 12 .

Data from the first experiment carried out at the beginning of July showed again the difference in photosynthesis rate of pine from Poland and Turkey (table 13).

Table 13

Mean values of photosynthesis and respiration rates, greenhouse, pot experiments during the second vegetation season

(IRGA-deteı mination)

\begin{tabular}{|c|c|c|c|}
\hline \multirow{2}{*}{$\begin{array}{c}\text { Period } \\
\text { of investigation }\end{array}$} & \multirow{2}{*}{ Rate of process ( $\mathrm{mg} \mathrm{CO} \mathrm{CO}_{2} /$ hour) } & \multicolumn{2}{|c|}{ Provenance } \\
\hline & & Nowy Targ & Eskishaher \\
\hline & $\begin{array}{l}\text { Photosynthesis } \\
\text { per } 1 \mathrm{~g} \text { of needles dry weight } \\
\text { per } 1000 \text { needles }\end{array}$ & $\begin{array}{r}9.4 \\
47.8\end{array}$ & $\begin{array}{l}10.4 \\
34.4\end{array}$ \\
\hline June/July 1968 & $\begin{array}{l}\text { Respiration } \\
\text { per } 1 \mathrm{~g} \text { of needles dry weight } \\
\text { per } 1000 \text { needles } \\
(\mathrm{A}+\mathrm{R}) / \mathrm{R} \text { ratio (whole aerial part) } \\
(\mathrm{A}+\mathrm{R}) / \mathrm{R} \text { ratio (whole plant, root included) }\end{array}$ & $\begin{array}{l}1.12 \\
5.9 \\
9.3 \\
7.5\end{array}$ & $\begin{array}{r}0.97 \\
3.4 \\
11.2 \\
8.7\end{array}$ \\
\hline & $\begin{array}{l}\text { Photosynthesis } \\
\text { per } 1 \mathrm{~g} \text { of needles dry weight } \\
\text { per } 1000 \text { needles }\end{array}$ & $\begin{array}{r}6.6 \\
47.2\end{array}$ & $\begin{array}{r}6.2 \\
28.6\end{array}$ \\
\hline August 1968 & $\begin{array}{l}\text { Respiration } \\
\text { per } 1 \mathrm{~g} \text { of needles dry weight } \\
\text { per } 1000 \text { needles } \\
(\mathrm{A}+\mathrm{R}) / \mathrm{R} \text { ratio (whole aerial part) } \\
(\mathrm{A}+\mathrm{R}) / \mathrm{R} \text { ratio (whole plant, root included) }\end{array}$ & $\begin{aligned} & 0.88 \\
& 6.7 \\
\approx & 8 \\
& 5.0\end{aligned}$ & $\begin{aligned} & 0.88 \\
& 4.4 \\
\approx & 8 \\
& 5.7\end{aligned}$ \\
\hline
\end{tabular}

The difference was not as great as in Warburg determinations, but it was of the same character. Also the ratio $(A+R) / R$ was higher in Eskishaher pine, like in the parallel manometric determinations. Only the data calculated per 1000 needles gave opposite results in comparison with Warburg technique but this resulted from much greater difference in needles sizes in pot plants, in comparison with the nursery ones.

In experiment carried out in August the rate of photosynthesis was already remarkably lower in comparison with the rates obtained in July. This symptom of a photosynthetic winter depression advance is probably responsible for lack of noticeable difference in photosynthesis rate of plants of various provenances. 


\section{DISCUSSION}

The conclussions of this work may be of only limited value for sylviculture as only seedlings and young trees were investigated and, besides this, experiments are lacking of the same type but at the teritory of Turkey. However, from the paper of Saatçiglu (1967) carried out in scopes of the IUFRO-cooperation some information is available indicating that pines of Polish provenance exhibit good growth characteristies on plantation in Turkey and they are even better, in this respect, in comparison with the native ones. Determinations of needle length carried out on 10 years old plantation in Turkey showed the needles of native provenance to be shorter than those from Poland.

Similar differences in growth were also noted between Scots pine of central European origin and Turkish one in experiments carried out in USA (Gat he ru m et al. 1967). It appears that in experiments in Poland difference of the same character exists between these two pines.

In our investigations pine of Turkish provenance showed better growth than that from Poland but only during the juvenile stage of development i.e. in the first year of nursury experiment. Later on the superiority of pine from Poland was noted not only in the nursery but also in greenhouse experiments and it can be expected with great probability that the difference between these two pines will continue to increase in further development of the plantation.

Another difference between these two pines is various development of the root system: in all experiments pine of Turkish provenance showed lower shoot/root ratio than pine of Polish origin.

The experiments carried out with plants of various developmental stages and by use of different techniques clearly indicate that in almost every case photosynthesis rate of Eskishaher pine is higher than that of Nowy Targ provenance. This gives a further evidence that photosynthesis rate alone does not directly determine the plant productivity although it essentially contributes to the process of yield formation. Also the ratio $(A+R) / R$ which is sometimes considered to be an index of "respiration economy" (Polster 1950) does not show higher values for better growing strain, even when not only aerial parts but also the dissimilation of root system is included into the calculation.

These results agree with data of Gordon and Gatherum (1968), who also showed that rates of photosynthesis were higher in Scots pine provenances exhibiting rather lower rates of growth. The work of Gordon and Gatherum (1968), did not include the Turkish provenance but comparison of the Polish and Bulgarian ones indicates that pine of southern origin exhibits samewhat higher photosynthesis rate.

The apparent divergence between photosynthetic ability and dry matter accumulation is certainly connected with not fully comparable reference unit for expression of photosynthesis rate as the needles formation was not quite parallel in both investigated pines. The data indicate that needles of Eskishaher pine in experiments carried out in Poland are often smaller and perhaps the delayed growth of assimilatory organs in this strain causes that, in measurements 
carried out at the same time of the year, not the same growth stages are being campared. Another possibility is, that ecology of photosynthesis differs and in our experiments only the photosynthetic ability, in conditions close to optimum, was determined; hence we are not able to say what are the daily fluctuations of the process in natural environment and which one of these two pines was closer to its maximum photosynthesis rate. Indeed, data on the net assimilation rates obtained from the growth analysis of plants grown in field conditions have proved that despite of higher, in Eskishaher pine, photosynthetic ability found in laboratory, its net production resulting from all these interferring influences is lower than that of pine of Polish origin.

Nevertheless the essential question of this study - physiological differentiation within the species - has found some farther elucidation: if plants of various origin are cultivated at experimentaly uniform conditions the genotype differentiation appears not:only in morphology and growth rates but also in photosynthetic and respiratory activities. It is rather difficult to say at the moment, which of these processes - the growth course or the rates of basic physiological activities - are preliminary or secondary in character, but the main point is that these two pines are different in physiological respect.

The study on photosynthetic activity of pines of different provenance has also given some farther information on physiological properties of the species. It is seen that photosynthesis rate of pine needles may reach the maximum value of about $10 \mathrm{mg} \mathrm{CO}$. $/$ hour/ $\mathrm{g}$ of dry weight in conditions below the light saturation level which is relatively high in comparison to other authors data (see literature review: Żelawski 1967).

Also the maximum values of the net assimilation rate were, in our experiment during the first vegetation season, higher than those obtained by Jarvis and Jarvis (1964). These authors found the maximum rate of $P$. silvestris to be $22.7 \mathrm{~g} / \mathrm{m}^{2} /$ week which is equivalent to $26 \mathrm{mg} / \mathrm{g}$ of needles dry weight/day. The difference between our data and Jarvis and Jarvis results is probably due to different growth conditions which at artificial light in growth chamber were certainly poorer than in nursery. Rutter (1957) who also investigated Scots pine seedlings in nursery conditions obtained the maximum value $36 \mathrm{~g} / \mathrm{m}^{2} /$ week ( $\cong$ about $40 \mathrm{mg} / \mathrm{g}$ of needles dry weight/day) which is closer to our results. The decrease of the net assimilation rate towards the end of the vegetation season mainly results from the shortening of the daily duration of photosynthesis but we do not have any explanation of higher values found in Eskishaher pine during the 28 days in August and September.

The data on net assimilation rate calculated for seedlings of the third vegetation season are comparable with numbers given by Sands and Rutter (1959). The maximum values of their work obtained in conditions of excessive water supply were of the order of about $40 \mathrm{mg} / \mathrm{g}$ of dry weight of needles/day (as estimated from their data after transformation $\mathrm{m}^{2}$ into $\mathrm{g}$ of dry weight) which is only slightly higher than our values calculated for pine of Polish origin.

There is also another point in our investigation which seems to be of great interest. In both nursury experiments, in seedlings of the first and third vegetation 
season, the same character of the difference in number of needles per shoot was observed. It means, that either Scots pine from Turkey has higher number of needles than that from Poland which is connected with their different ecotypic character, or the process of differentiation itself is accelerated in pine of Turkish origin when cultivated in Polish conditions. It would be very interesting to compare the numbers of assimilatory organs per shoot in plants of Polish and Turkish origin but growing on plantations in Turkey. Having such data one would be able to say whether or not the average number of needles per shoot is a typical feature of the ecotype which may help at distinction of pines of various origin, or it is the effect of site and seed source interaction; in the latter case such information would greatly contribute to the question of factors affecting the course of the process of differentiation of organs in the growing tissues.

\section{SUMMARY}

During the first vegetation season in the nursery conditions pine of Turkish provenance showed better growth than that of Polish provenance. Later on the growth rate of Polish pine was better and the difference between provenances continued to increase during the second and third vegetartion season.

The examined pines were found to have various development of the root system. In all experiments pine from Turkey showed lower shoot/root ratio.

The investigated pine strains differed also in number of needles per plant. Eskishaher pine had usually more number of needles per shoot but the needles were often smaller than those of Nowy Targ pine.

Photosynthesis rates of Eskishaher pine were higher than those of Nowy Targ pine, but there was no significant difference between the investigated pines in respiration rate (except the juvenile stage).

The results of the investigation indicate that Scots pine of two distant localities of origin when cultivated at a similar growth conditions exhibits significant differences in morphological and physiological features.

\section{ACKNOWLEDGMENTS}

Thanks are due to Doc. dr W. Żelawski for his helpful advice during the course of this investigation, and also the considerable assistance given by Mgr. Inż. A. Łotocki in the laboratory is greatly acknowledged.

Department of Forestry

Warsaw Agricultural University

Rakowiecka 26/30, Warsaw-Poland.

(Entered: November 19, 1968.)

\section{REFERENCES}

Białobok S., 1967, Zmienność ekotypowa sosny zwyczajnej ,,Zarys Fizjologii Sosny Zwyczajnej” red. Białobok S., Żelawski W., PWN Poznań (17-29).

Bruinsma J., 1963, The quantitive analysis of chlorophyll a and b in plant extracts. Photochem, and photobiol. (Chlorophyll Metabol. Symp.), 2: 251-249. 
Gatherum G. E., J. C. Gordon and B. F. S. Broerman, 1967, Physiological variation in Scotch pine seedlings in relation to light intensity and provenance, Iowa State Journ. Sci. 42: 19-26.

Gordon J. C., Gatherum G. E., 1968, Photosynthesis and growth of selected Scoteh pine populations, Silva Fennica 2: 183-194.

Jarvis P. G., Jarvis M.S., 1964, Growth rates of woody plants, Physiologia Plantarum 17: $654-666$.

Kozlowski T. T., Keller T., 1966, Food telation of woody plants, Bot. Rev. 32: 293-382.

Lotocki A., 1969, Analiza wzrostowa jako metoda oceny produktywności roślin. Wiad. Bot. (in press).

Mackinney G., 1941, Absorption of light by chlorophyll solution, Journ. Biol. Chem. 140: 315-322.

Polster H., 1950, Die physiologischen Grundlagen der Stofferzeugung im Walde, München 1950.

Rutter A. J., 1957, Studies in growth of young plants of Pinus silvestris. I. The annual cycle of assimilation and growth, Annals of Botany N. S. 21: 399-426.

Saatçiglu F., 1957, Results of the 25 -years provenance experiment established by using 16 Scotch pine of the European and 1 of native provenances in Turkey, Silva Silvae genetica 16: 172-177.

Sands K., Rutter A. J., 1959, Studies in the growth of young plants of Pinus silvestris L. II. The relation of growth to soil moisture tension, Annals of Botany, N. S. 23: 269-284.

Warburg O., Krippahl G., 1960, Weiterentwicklung der manometrischen Methoden, Z. Naturforschung, 15b: 786-787.

Żelawski W., Góral I., 1966, Gazowy analizator (IR) w badaniach z zakresu fizjologii i ekologii roślin. Wiadomości Botaniczne 10(2): 75-85.

Żelawski W., 1967, Variation in the photosynthetic efficincies of trees with special reference to Scots pine (Pinus silvestris L.), Proceeding of the 14th IUFRO-Congress, Section 22, München.

Żelawski W., Kinelska J., 1967, Photosynthesis and respiration of Scots pine (Pinus silvestris L.) seedlings grown in water culture from seed of various provenance, Acta Soc. Bot. Polon. 36: $587-598$.

Żelawski W., Kinelska J., 1967, Photosynthesis and respiration of Scots pine (Pinus silvestris L.) seedlings of various provenance grown under different light conditions, Acta Soc. Bot. Polon. 36: $713-723$.

Żelawski W., Kinelska J., 1968, Comparative study in the photosynthetic ability of Scots pine (Pinus silvestris L.) young trees of different provenances, Annual report from the Department of Forestry, Warsaw Agricultural University.

Żelawski W., Kucharska J., 1967, Winter depression of photosynthetic activity in seedlings of Scots pine (Pinus silvestris L.), Photosynthetica 1 (3-4): 207-217.

Fotosynteza, oddychanie $i$ produkcja suchej masy u siewek sosny zwyczajnej (Pinus silvestris L.) pochodzenia polskiego (Nowy Targ) $i$ pochodzenia tureckiego (Eskishaher)

\section{Streszczenie}

Badano intensywność procesów fotosyntezy, oddychania oraz gromadzenia suchej masy u siewek sosny zwyczajnej pochodzenia polskiego (Nowy Targ) i tureckiego (Eskishaher). Badania przeprowadzono na jedno, dwu i trzyletnich siewkach hodowanych w wazonach w hali wegetacyjnej i w szkółce leśnej Lasów Doświadezalnych SGGW w Rogowie. Intensywność asymilacji netto (NAR) obliczano z danych dotyczących gromadzenia suchej masy; mierzono również intensywność fotosyntezy za pomocą aparatu Warburga i analizatora gazowego (IRGA). Zawartość chlorofilu oznaczano spektrofotometrycznie. 
W pierwszym roku wegetacji w warunkach naturalnych sosna pochodzenia tureckiego wykazywała większy przyrost niż sosna pochodzenia polskiego. W latach następnych natomiast obserwowano większy przyrost u sosny z Nowego Targu zarówno w doświadczeniach prowadzonych w szkółce, jak i w kulturach wazonowych. W ciągu okresu badań stosunek pędu do korzenia był zawsze mniejszy u sosny pochodzenia tureckiego niż u sosny pochodzenia polskiego. Ponadto siewki różniły się wyraźnie wielkością i ilością igieł: sosna pochodzenia tureckiego wytwarzała więcej igieł, były one jednak zwykle mniejsze.

Sosna pochodzenia tureckiego wykazywała większą intensywność fotosyntezy.

Intensywność oddychania obu badanych sosen była prawie jednakowa (z wyjątkiem pier wszego roku wegetacji).

Wyniki badań wskazują na istnienie fizjologicznych i morfologicznych różnic między badanymi sosnami. 